\title{
A LOOK AT THE GENRE OF UZBEK FOLK MUSIC
}

\section{Yuldashev A.}

Teacher, Fergana Regional Branch of Uzbekistan State Institute Of Arts And Culture, Uzbekistan

\section{Azizov S.}

Teacher, Fergana Regional Branch Of Uzbekistan State Institute Of Arts And Culture, Uzbekistan

Boboyev V.

Teacher, Fergana Regional Branch of Uzbekistan State Institute Of Arts And Culture, Uzbekistan

\section{ABSTRACT}

This article tells about the Uzbek folk music culture, the diversity and style of Uzbek songs.Uzbek music culture is developing in an ancient and colorful way, while embodying modern traditions. First of all, it reflects the unique forms and styles of unique folk music, classical musical heritage, national composition, modern composition, as well as folk amateurism and vibrant popular pop art.

\section{KEYWORDS:- Melody, song, music, performance, lapar, yalla, ceremony.}

\section{INTRODUCTION}

Thanks to independence, the focus on our national and spiritual values, the revival of our forgotten traditions in a historically short period of time, has become a priority in the process of renewal and reform for the sake of continuous development.Efforts to develop cultural and musical ties with neighboring and far abroad countries have also become important.

Also, the musical heritage of the Uzbek people, which has its roots in ancient times, is still heard today. He combines his folk art (i.e., folklore) as well as songs and instruments developed in terms of melody structure - epics and maqom music.Heroic as well as heroic - lyrical works epics also play an important role. The genres of Uzbek musical instruments, as well as the genres of musical instruments associated with the practice and style of music, are characterized by great diversity and richness.Uzbek folk music, like any other folk art, embodies the aspirations of workers, their lives and morals, and the struggle for social and national liberation. The diversity of Uzbek folk music, the richness of genres and the diversity of its place in life are connected with this.

Along with Uzbek folk music, samples of Uzbek folklore are our invaluable heritage, which has been passed down from generation to generation and renewed for centuries, expressing the culture and spirituality of the people.That is why the head of our country Shavkat Miromonovich Mirziyoyev said: "We have a great history worth envying.We have enviable creative organizations, writers, great ancestors.We have incomparable 
riches that are worth envying. And I believe that if we are lucky, we will have a great future, a great literature and art, which is worth envying, "he said, adding that this is directly related to folklore (Mirziyoyev, 2017).

Indeed, one of the priorities of folklore is to always respect national values, to study them in detail and make them the object of scientific research.

In this regard, it is worth noting that in our country, along with the highest examples of modern art and literature, great work is being done to make the rich spiritual heritage, which has withstood the test of centuries, a partner, a breath of fresh air for present and future generations.

The essence of art is life, the reality around us, the person and his inner world - his thoughts and feelings. Art assimilates reality through the creation of artistic images rather than other forms of human activity.He seems to recreate the world in a way that directly affects a person's emotions and consciousness. However, the artist does not copy life, events and things. He selects the most common, typical features of an image, understands them all, changes the image, and then embodies it in the form of paintings, poems, and music.Of course, the work of any artist preserves the personal complexity of the author. This is because the objective material of the external world is reworked in the artist's mind and re-created as an original, original creation. However, at the same time, every creative work is also considered a product of public consciousness.Because it has to do with a certain social psychology, a country, a historical event. The social aspect of art is manifested in the fact that one feels the connection of one's contemporaries and people with the past and humanity through artistic images. True art, while creating eternal artistic values, justifies the continuity of generations.
Thus, works of art are a picture of both life and creativity. But art forms are not able to depict different aspects of life to the same extent. Each type of art is characterized by its own means and principles of expression. So what is the art of music? What are its goals and objectives?

Music is the art of intonation, an artistic reflection of reality expressed in sounds. It reflects and enriches the being in a unique way, and helps to understand and change it. It is known that music plays an important role in the life of society.Music is a unique tool that leads a person to spiritual values, serving as a symbol of a person's participation in life and social life, work and leisure. It is considered to be an effective tool of aesthetic education, which shapes the spiritual world and moral goals of the individual.Music itself, its creators, performers and listeners, is an important part of the culture of society. There is no doubt that music is closely related to other arts.Their lively connection is evidenced by the closeness of the intonational basis of music to literature, the rhythmic coherence of which is similar to the art of poetry and dance, the harmonious structure of their works in accordance with architectural forms. I would like to add that works of literature, fine arts, and sculpture often serve as the basis for musical works.Music has this or that content, which is revealed through musical images. These are natural landscapes, events and situations in social life, the inner spiritual world of man. Music is able to express a person's feelings and moods. At the same time, it has the ability to depict natural landscapes, embody images of movement, imitate the sincere sounds of life (birdsong, thunder).

Sound is a physical phenomenon. In turn, the concept of "sound" includes a series of different events, which are interconnected. The source of sound is the vibrational motion of an object (e.g., a wire string).As a result of these actions, sound 
waves are created in the air. They affect the auditory system, travel through the auditory nerve to the brain, and produce sound sensations.

In nature, the sounds that the human ear hears are endless. They are noisy - natural sounds like knocking, rustling, squeaking, and musical singing sounds.

Noisy sounds are also used in musical works. For example: the sounds of a circle, drums, drums, plates, spoons. The human voice is divided into artificial sounds, such as the sound of a musical instrument.Musical sounds are the main means of the art of music and serve to reflect the reality around them. They have been selected in the course of centuries of development of musical culture. organized into a specific system.The basis of the elements of musical expressiveness is the musical sound has its own characteristics. These properties result from the vibration speed, vibration width, vibration duration, and the number and quality of the components of the vibrating body.Genres of Uzbek songs and instrumental music are divided into two groups according to their function and place in life. The first is songs and melodies that are performed only for a certain period of time or under certain conditions. These are: family songs, labor songs.These are lullabies and those that are performed in various ceremonies and performances. The second is songs and musical instruments that can be performed at any time and in any situation.These include: lapar, yalla, tune, song, instrumental melodies, chulama and epic melodies.Each group has its own characteristics. For example, the theme of the first group of song genres, the performance of which requires a certain time or condition, is related to a particular ceremony or other situation, and is distinguished by the fact that it is almost indistinguishable from it.Deviations from the main theme, which are sometimes encountered, are in the context of lyrical thinking and generalized exhortations.Of these, "Yor-yor" songs have existed among the people for a long time, and examples of them are described in the book "Songs of Uzbek folk ceremonies" by Muzayyana Alaviya."Yor-yor" has a wide range of topics, sometimes humorous, sometimes cheerful, sometimes light humor, sometimes bitter humor.This is due to many aspects, such as the moral qualities of the unmarried girl, the wedding, and finally the young man who is getting married, his position in society, and his human qualities. In addition, the predominance of the melody in "yor-yor" depends on its performers.For example, when bringing a girl to the groom, the free verses of the song "yor-yor" are sung by the bride's wife or the girl's relative, in which case the bride's good qualities, good manners, and perfection are praised.If "Yor-yor" is performed by the bride's friends, the song may be dominated by the girl's grief, the loss of her parents, the family where she was born and raised, the forced marriage, the inability to reach the lover.So, there are a lot of reasons for what tone, what tone prevails in the world. Uzbek "yor-yor" can be divided into several types depending on the style of performance and the nature of the music.So far, they can be conditionally divided into species such as Fergana, Zarafshan and Khorezm "yor-yor". With further research and observation, the number of these species may either increase or decrease, as the future will show.In general, the melody of all types of "yor-yor" is based on the harmony of narrow-range melodies with a certain metrorhythmic order. Each of them differs in its melody structure, melody character, rhythm, performance style, dialect and emotional impact.Labor songs are sung only during labor: double plowing, harvesting, cotton picking, spinning, hunting, fruit picking, and so on. In these songs, human experiences, labor, types of work, and natural phenomena are 
compared.Lullaby songs are the sorrows that mothers inflict on their brown children. In ancient times, the gods were the voices of dreams and hopes of mothers full of human love, the wrath and resentment against unfaithful, cruel lands, the troubled times, the cruel parents.There could beheard the cries of a girl, a slave, a concubine, who had been forcibly separated from her lover, who was being sold for a large sum of money. Modern lullaby songs, on the other hand, take on a completely different modern content.

Lullaby songs are sung by mothers, grandmothers, sisters, women to make child sleep. The difference between lullaby song and other songs is that they can be sung at any time in a home with babies. Lapars, on the other hand, differ from other songs by their eventfulness, their rivalry, and their dialogue with two singers.Lapar's texts are mostly based on love, humor, domestic violence, and parents 'relationships with their children are sometimes based on light, sometimes bitter laughter. As a song, Lapar has a small-scale, two-part structure.Many of the features of Lapar's musical poetic basis are the same for the song (even though the song is repetitive).

The terma songs (collection songs) consists of poems on various topics, performed by poets, poetesses, poets, musicians, singers, at weddings, trips, festivals, and in public places in general.Usually, a national terma song is sung to attract the attention of the audience and to set the mood for the narrator and the listener. The terms vary in subject matter. But most of them are didactic songs that call for courage and justice, singing about the bitterness of the world, high and low, good and bad.The melodies are characterized by a certain recitativeness of their melody, a narrow range and a compact form. As a genre, the song consists of independent quartets of finger weight, consisting of a relatively small range of melodies.At the same time, a complete melodic structure is adapted to each verse. The song is one of the most popular genres, which is distinguished by the diversity and versatility of its content.The melodies are smooth and precise. The song is characterized by repetitions after each verse or after each verse or half of it. Many of the features of the song's musical poetic features are also unique to Lapar.

Yalla has a special place in the Uzbek music genre. It is usually performed in combination with singing and dancing.The melody of the first is relatively narrow, with each stanza and its play being sung by a soloist, and the refrain by each group of musicians or singers.The melody of the second is a wide range, starting with a busy refrain and ending with a refrain. The song is characterized by the length of its melody and the wide range of development, a significant syncopation of the rhythm. Usually, the hymn is based on the romantic-lyrical content of the poetic text, which expresses longing, pain and sorrow. Advanced examples of singing belong to the professional music of the oral tradition.This includes another type of song genre - the big song or the patnis-patnusaki song. Large songs are the main melodic structures that differ in the declamatory nature of their melody, the breadth of their range - about three octaves.

\section{REFERENCES}

1. Sh.Mirziyoyev. Buyuk kelajagimizni mard va olijanob xalqimiz bilan birga quramiz. Toshkent: O'zbekiston nashriyoti. 2017.

2. Mirziyoyev Sh.M.Erkin va farovon, demokratik O'zbekiston davlatini birgalikda barpo etamiz. - Toshkent: O'zbekiston, 2016. - 56 b.

3. Mirziyoyev SH.M. Tanqidiy tahlil, kat'iy tartib-intizom va shaxsiy javobgarlik - har bir rahbar faoliyatining kundalik qoidasi 
bo'lishi kerak. - Toshkent: O'zbekiston, 2017. - 104 b.

4. Mirziyoyev SH.M. Qonun ustuvorligi va inson manfaatlarini ta'minlash - yurt taraqqiyoti va xalq farovnligining garovi. Toshkent: O'zbekiston, 2017. - 48 b.

5. Mirziyoyev SH.M. Buyuk kelajagimizni mard va olijanob xalqimiz bilan birga quramiz. - Toshkent: O‘zbekiston, 2017. $488 \mathrm{~b}$.

6. 2017-2021 yillarda O'zbekiston Respublikasini rivojlantirishning beshta ustuvor yo'nalishi bo'yicha Harakatlar strategiyasi.

7. Boltaboeva, U., Abdunazarov, Z., \& Usmonov, S. (2021). The balance of language and speech in the Uzbek theater. ASIAN JOURNAL OF MULTIDIMENSIONAL RESEARCH, 10(4), 788-792.

8. Haydarov, A., Akbarov, T., \& Abdunazarov, Z. (2020). High purpose and leading action. ACADEMICIA: AN INTERNATIONAL MULTIDISCIPLINARY RESEARCH JOURNAL, 10(12), 609-615.

9. Akbarova, M., Tursunova, G., \& Abdunazarov, Z. (2020). Pedagogical aproaches to the formation of musical literacy of students in the sytem of Higher Education. European Journal of Arts, (1), 125-128.

10. Akbarova, M., Tursunova, G., \& Abdunazarov, Z. (2020). Pedagogical aproaches to the formation of musical literacy of students in the sytem of Higher Education. European Journal of Arts, (1), 125-128.

11. Boltaboeva, U., Gofurova, B., Pulatov, R., \& Mamatkulov, B. (2020). Methods of improving the young actors speech. ACADEMICIA: AN INTERNATIONAL
MULTIDISCIPLINARY

RESEARCH
12. Boltaboeva, U., Abdunazarov, Z., \& Usmonov, S. (2021). The balance of language and speech in the Uzbek theater. ASIAN JOURNAL OF MULTIDIMENSIONAL RESEARCH, 10(4), 788-792.

13. Usmonov, S., Boltaboeva, U., \& Akbarov, $\mathrm{T}$. (2021). Principles of working on a monologue with future actors. Asian Journal of Multidimensional Research, 10(6), 28-38.

14. Boltaboeva, U., Usmonov, S., \& Akbarov, T. (2021). A Look at Askia Art. Annals of the Romanian Society for Cell Biology, 25(6), 2277-2284.

15. Usmonov, S., Boltaboeva, U., Rahmonova, N., \& Akbarov, T. (2021). Pedagogical Approaches To Educating Future Actors. The American Journal of Interdisciplinary Innovations Research, 3(05), 85-90.

16. Boltaboeva, U., Andunazarov, Z., \& Tursunova, G. (2020). Importance of tongue twisters and proverbs in overcoming speech defects. Journal of Advanced Research in Dynamical and Control Systems, 12(2), 2902-2905.

17. Boltaboeva, U. (2019). Using Oral Folk Art Methods in Improving Speech Technology. Eastern European Scientific Journal, (1).

18. Boltaboeva, U., Sh, U., \& Rahmonova, N. (2019). Creative person-the role of live word in educating an actor. European Journal of Arts, (3).

19. Boltaboyeva, U., Rakhmonova, N., \& Usmonov, S. (2020). Characteristics of speech Art: problems and solutions. ACADEMICIA: An International Multidisciplinary Research Journal, 10(4), 559-567. 
20. Tursunova, G., \& Karimov, B. (2020). Factors that should be considered in musical theater actors education. ACADEMICIA: An International Multidisciplinary Research Journal, 10(11), 57-61.

21. Tursunova, G. (2021). BALET RAQS SAN'ATINING O'RNI VA TARIXIY TARAQQIYOTI. Oriental Art and Culture, (6).

22. Tursunova, G., \& Karimov, B. (2020). PEARLS OF UZBEK NATIONAL DANCE. International Engineering Journal For Research \& Development, 5(Conference), 4-4.

23. Yunusov, G. X., Juraev, I., \& Ahmedov, R. The European Journal of Arts, Issue $1 / 2020$.

24. Yunusov, G., Ahmedov, R., Jurayev, I., \& Yuldasheva, S. (2021). A Look At The Folklore of Fergana Valley or History of A Song in The Series of Tanovar. Annals of the Romanian Society for Cell Biology, 25(6), 2225-2232.

25. Yunusov, G., Juraev, I., \& Ahmedov, R. (2020). A LOOK AT THE REGIONAL SEASONAL FOLKLORE AND THEIR ORIGIN. THE ROLE AND IMPORTANCE OF FOLKLORE IN THE DEVELOPMENT OF DANCE ART. European Journal of Arts, (1), 121-124.

26. Sohibaxon, Y. (2021). O'ZBEKISTONDA KUTUBXONACHILIK SOHASINING RIVOJI. Oriental Art and Culture, (7), 260-268.

27. Yunusov, G., Ahmedov, R., Jurayev, I., \& Yuldasheva, S. (2021). A Look At The Folklore of Fergana Valley or History of A Song in The Series of Tanovar. Annals of the Romanian Society for Cell Biology, 25(6), 2225-2232.
28. Yuldasheva, S., Habibjonov, I., \& Haydarov, A. (2020). Librarianship in the formation of book reading. Journal of Advanced Research in Dynamical and Control Systems, 12(2), 2925-2927.

29. Yunusov, G., Ahmedov, R., Jurayev, I., \& Yuldasheva, S. (2021). A Look At The Folklore of Fergana Valley or History of A Song in The Series of Tanovar. Annals of the Romanian Society for Cell Biology, 25(6), 2225-2232.

30. Yuldasheva, S., \& Madumarova, M. (2020). TASKS AND CONTENT OF BIBLIOGRAPHIC WORKS. European Journal of Arts, (1), 148-152.

31. Yunusov, G. X., Juraev, I., \& Ahmedov, R. The European Journal of Arts, Issue $1 / 2020$.

32. GofirjonYunusov, R. A., Jurayev, I., \& Yuldasheva, S. (2021). A Look at the Folklore of Fergana Valleyor History of a Song in the Series of Tanovar. Annals of the Romanian Society for Cell Biology, 25(6), 2822-2827.

33. Yunusov, G., Juraev, I., \& Ahmedov, R. (2020). A LOOK AT THE REGIONAL SEASONAL FOLKLORE AND THEIR ORIGIN. THE ROLE AND IMPORTANCE OF FOLKLORE IN THE DEVELOPMENT OF DANCE ART. European Journal of Arts, (1), 121-124.

34. Talaboyev, A., Yunusov, G., \& Ahmedov, R. (2020). Local methods of traditional singing. Journal of Advanced Research in Dynamical and Control Systems, 12(2), 2916-2920.

35. Yunusov, G., Ahmedov, R., Jurayev, I., \& Yuldasheva, S. (2021). A Look At The Folklore of Fergana Valley or History of A Song in The Series of Tanovar. Annals of 
the Romanian Society for Cell Biology, 25(6), 2225-2232.

36. Yunusov, G., Juraev, I., \& Ahmedov, R. (2020). A LOOK AT THE REGIONAL SEASONAL FOLKLORE AND THEIR ORIGIN. THE ROLE AND IMPORTANCE OF FOLKLORE IN THE DEVELOPMENT OF DANCE ART. European Journal of Arts, (1), 121-124.

37. Usmonov, S., \& Talaboyev, A. (2021). Work of the director with an artist. ACADEMICIA: An International Multidisciplinary Research Journal, 11(3), 2407-2410.

38. Talaboev, A., Akbarov, T., \& Haydarov, A. (2020). SONG PERFORMING IN TRADITIONAL PERFORMING ARTS: PAST AND PRESENT TIM. European Journal of Arts, (1), 85-88.

39. Dadaboev, Y., \& Dehqonov, R. Hordo Structures in Central Asian Architecture.

40. Utaganov, R., Dehqonov, R., \& Tuxtasinov, M. (2020). MAIN ADVANTAGES OF TEACHING METHODS IN ARTS. European Journal of Arts, (2), 146-148.

41. Usmonov, S., Utaganov, R., \& Dehqonov, R. (2020). Director's knowledge and approach in performing classical plays. Journal of Advanced Research in Dynamical and Control Systems, 12(2), 2921-2924.

42. Haydarov, A. (2019). AKTYORLIK SAN'ATIDA VOKALNING O 'RNI. Интернаука, (19-4), 55-56.

43. Haydarov, A. (2020). QOSHIQLAR ORQALI O'QUVCHILARDA VATANPARVARLIK TUYGUSINI SHAKLLANTIRISH. Oriental Art and Culture, (IV).

44. Haydarov, A. (2021). The role of Uzbek folklore in the aesthetic development of youth. ACADEMICIA: An International
Multidisciplinary Research Journal, 11(3), 1973-1977.

45. Askarova, M. (2020). Homil yakubov's views on navoi studies. ACADEMICIA: AN INTERNATIONAL MULTIDISCIPLINARY RESEARCH JOURNAL, 10(12), 788-792.

46. Askarova, M. (2021). Homil Yakubov's views on Oybek lyrics. ACADEMICIA: An International Multidisciplinary Research Journal, 11(3), 2412-2415. 